\title{
REFOMULASI EPISTEMOLOGI HIJRAH DALAM DAKWAH
}

\begin{abstract}
Aswadi $^{*}$
A bstrak: Thepaper disarsesstheidea of Hijrahanditshistoricrdein theprocess of Idamic propagation (da'wah). Hijrahisa physical migation fromMakkahtoMedimah; amigation that hasimplied bothreligious and spinitual transofmation In itsliteral meaning Hijrahis simply to movefrom one placeto andher. In thehistory of da'vah, Hijrah is a monent in which Islamundarwent a process of dhange and transition fromone situation into another. Hijrah was thefirst stepping stonetonard the morevibrant and adive propagation of Isam Thepaper deals with this notion of Hijrah as thestrategicmovetoward thesurcessfil mission of disseminatingIsam Theseissues togther with themanyimplicationsthat Hijrah has will bethefous of this paper. The peper argues that Hijrah is not simply to makea physical movement fromoneplacetoanothe. It isalsoabout thespinitual andrdigiustransfomation of theMusimumma Through Hijrahanewsoial, political andailtural order isresumeted Tomakear disaussion mmelivey, thepaper will refer tomanyQur'anicversesandprophetic traditionsthat speak of Hijrahandinterpret themin thelight of thehistoricHijrah Hence, welook at Hijrah as not only an eent in history, but also a nom of reigion that has a spinitual value of its own
\end{abstract}

Keywords: hijrah, dakwah, spinitual value

\section{Pendahuluan}

D akwah sebagai usaha untuk merealisasikan ajaran Islam pada semua aspek kehidupan manusia telah menjadi bagian yang tak terpisahkan dengan tanggung jawab umat Islam. ${ }^{1}$ Rasulullah Saw sebagai da'i pertama dalam melaksanakan tugasnya ditempuh melalui berbagai pendekatan strategis sebagaimana tampak ketika beliau berada di Makkah (610622 M.), dakwah disebarkan melalui pendekatan kekeluargaan dengan cara diam-diam yang hanya sekedar memberi pelajaran dan petunjuk, ${ }^{2}$ kemudian diperluas dan dikembangkan melalui pendekatan terbuka dan terang-terangan ${ }^{3}$ dengan tanpa menghiraukan penghinaan dan ancaman penentangnya. ${ }^{4} \mathrm{D}$ alam upaya ini, dakwah mampu menembus ke berbagai penjuru, termasuk Ka'bah dan tempat-tempat orang Quraisy berkumpul. Namun, ketika dakwah tersebar secara terbuka dan jumlah pengikutnya semakin bertambah banyak, menyebabkan kaum Q uraisy bertambah keras tantangannya kepada Nabi Muhammad Saw. ${ }^{5}$

Setelah Nabi Saw di Madinah (1-11 H. = 622-632 M.) dakwah telah mampu menumbuhkan ikatan persaudaraan maupun ukhuwah Islamiah. Sebagai langkah pertama Nabi Saw mempersatukan kaum Ansłgr dan Muhajirin yang berbeda suku dan adat istiadat,

\footnotetext{
*Fakultas D akwah InstitutAgama Islam Negeri (IAIN) Sunan Ampel, Surabaya. Email: aswadi@ sunan-ampel.ac.id ${ }^{1}$ Menurut kesepakatan ulama, dakwah tersebut merupakan suatu kewajiban. Muhł̇mmad A buZahrah, a-Da'wah ilasl-Idam(t.t.: D asal-Fikr, t.th), 33-34 dan 129.

${ }^{2}$ Misalnya dalam surah al-Shu'arasayat 214-216. Lihat al-Qur'an, 26 (al-Shu'arał: 214-216. Lihat juga Amin S⿺廴d, Nashatal-Dankahal-Isamiyah(K airo: Isaæal-Babiæl-Hąlabi>t.th.), 5-7.

3al-Qur'an, 15 (al-Hijr): 94.

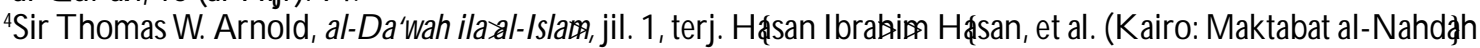
al-Mislisist.th.), 158-164.

${ }^{5}$ A. Hasjmy, Dustur DaknahmmenuntAl-Qur'an(Jakarta: Bulan Bintang, 1984), 352.
} 
yang menurut ukuran masa itu sangat sulit untuk dipersatukan, sehingga terbentuklah suatu umat laksana sebuah bangunan yang bagian-bagiannya saling memperkuat satu sama lain. Persaudaraan itu melahirkan kekuatan baru bagi umat Islam dalam mengembangkan dakwah, terutama setelah adanya perintah jihad dari Allah Swt dengan maksud membela diri dan melindungi dakwah untuk menghadapi kekejaman orang-orang kafir Q uraisy yang tidak henti-hentinya menentang Nabi Saw bahkan bertambah bringas dan mengganas setelah mereka bersekongkol dengan umat Yahudi dan Nasrani yang ada di Madinah dan sekitarnya. Keadaan ini menjadikan umat Islam melakukan perlawanan dan berhasil mengalahkan mereka beserta sekutunya ${ }^{6}$

Titik awal peristiwa hijrah tersebut merupakan momentum sejarah paling besar yang pernah disaksikan oleh umat manusia. Peristiwa ini benar-benar bermula dari sekelompok kecil orang-orang lemah yang tertindas dan hidup dalam kungkungan dominasi politik dan ekonomi serta kultur dari kelas penguasa Quraisy yang tiran, menyebakan mereka disiksa dan dikejar-kejar hidup dalam perantauan tanpa sempat mengumpulkan bekal material melintasi pilar hijrah. D ari seberang pilar yang monumental itu, di bawah kepemimpinan Nabi Muhammad Saw mereka membuat sejarah titik balik, dari segelintir orang yang terluntalunta, mereka menang yang hanya dalam perjalanan waktu 8,5 tahun saja, mereka menjelma menjadi umat baru, mampu mengalahkan musuh yang dahulu perkasa dan menganiaya mereka. Musuh itu menyerah kalah dan pasrah. Mereka menerima penyerahan bekas-bekas musuhnya dengan tanpa dendam, melainkan justru menjalin persahabatan di antara mereka dengan penuh keramahan, pesona dan kewibawaan semakin meningkat dan lebih menguat. ${ }^{7}$

Realitas hijrah dari sudut pandang historis sebagaimana penjelasan di atas akan lebih bermakna jika tinjauannya diperluas pada kajian normatif sebagaimana yang diisyaratkan dalam al-Q ur'an maupun al-Sunnah. Perpaduan tinjauan historis dan normatif ini diharapkan dapat mengantarkan pada pemahaman holistik dan komprehensif dalam sistem pengembangan dakwah. Karena itu, kajian tematis terhadap pemaknaan kembali tentang hijrah, baik secara tekstual maupun kontekstual merupakan sebuah kebutuhan dan tuntutan yang mendesak untuk diwujudkan dalam sebuah perumusan yang mencakup nilai-nilai religius, rasional, aplikatif dan fungsional dalam berbagai aspek kehidupan umat manusia. Fokus kajian tematis ini lebih mengarah pada studi hadith dengan berbagai dimensinya dalam sebuah tema "Reformulasi Makna Hijrah dalam Dakwah".

\section{Terminologi Hijrah}

Terminologi hijrah dapat ditelaah melalui berbagai dimensi. Secara etimologis, kata hijrah berasal dari bahasa Arab yang pada dasarnya tersusun dari huruf-huruf ha',jimdan ra's

${ }^{6}$ Ibid., 365. Lihat juga Arnold, al-Da'wahilasl-Isam 41-42. Perkembangan dakwah sebagaimana tampak pada uraian di atas menunjukkan bahwa peristiwa hijrah merupakan titik tolak dari kebangkitan dan perluasan ajaran Islam. Pelaksanaan hijrah dari Makkah menuju Madinah bagi Mahmud Salttł bukan berarti lari untuk menyelamatkan diri karena ketidakmampuan menghadapi kekuatan musuh yang lebih besar, apalagi untuk kepentingan harta benda dan merebut kekuasaan, tetapi hijrah tersebut hanya dilakukan sebagai kelanjutan dari hijrah hati nurani sebagai realisasi menegakkan kebenaran dan menghancurkan kebatilan, yang oleh Muhammad al-Fahman dikenal sebagai revolusi memadamkan kekegelapan jiwa, kegelapan kepercayaan, kegelapan masyarakat yang penuh dengan kejahatan dan kerusakan menuju bumi yang akan memancarkan cahaya kebenaran dan tauhid. Lihat Hasanuddin, RhetrikaDakuahdan Publisitik dalamKeperiminan(Surabaya: Usaha Nasional, 1982), 94-95. ${ }^{7}$ Saifuddin Zuhri, SeecahDakwah (Jakarta: Al-Maarif, 1983), 126-127. 
dengan dua pokok kandungan makna. Petama, hijrah berarti putus pada satu sisi dan persambungan pada sisi lain. Misalnya: sekelompok orang meninggalkan sebuah perkampungan menuju perkampungan lainnya, sebagaimana sahabat muhajirin yang meninggalkan Makkah menuju Madinah. Kedua, kata tersebut berarti telaga yang luas, dikatakan demikian karena telaga itu merupakan sesuatu yang menghentikan air. ${ }^{8}$ al-Raghib juga mengungkapkan bahwa kata tersebut pada dasarnya berarti putus dan meninggalkan sesuatu. ${ }^{9}$ Pengertian hijrah yang disebut terakhir ini, setidaknya dapat dikembangkan menjadi tiga kategori. Petama, kata hijrah berarti terlepasnya manusia dari yang lain, baik berupa fisik, ucapan maupun perasaan. Keedua, hijrah berarti ke luar dari perkampungan yang kafir menuju perkampungan yang mukmin. Ketiga, hijrah berarti meninggalkan akhlaq dan nafsu yang tercela maupun meninggalkan dosa dengan segala bentuknya menuju Allah Swt. ${ }^{10}$

Secara terminologis, kata hijrah diartikan dalam rumusan yang berbeda oleh ulama yang satu dengan lainnya. Ibnu Arabi menegaskan bahwa yang dimaksud dengan hijrah adalah ke luar dari daerah pertempuran menuju daerah Islam (damai). ${ }^{11}$ Pendapat lain mengatakan bahwa hijrah dalam perspektif historis dapat dilihat dari dua sisi: Petama, hijrah berarti berpindah dari daerah yang menakutkan menuju daerah yang aman. Keelua, hijrah berarti berpindah dari daerah kekafiran menuju mukmin. Dalam pada itu, hijrah juga dapat dilihat dari perspektif shariłah, yaitu meninggalkan segala sesuatu yang dilarang oleh Allah Swt. ${ }^{12}$ Pengertian yang terakhir ini sejalan dengan pendapat yang mengatakan bahwa hijrah adalah mendekatkan diri pada Allah Swt. Hal ini tidak akan terwujud secara sempurna dengan tanpa meninggalkan berbagai dosa dan kesalahan. ${ }^{13}$ Lebih jauh dalam kitab FathlalBari lijelaskan bahwa hijrah itu dapat dibedakan menjadi dua, yaitu: hijrah secara lahir dan batin. Secara batin, hijrah berarti meninggalkan segala sesuatu yang mendorong nafsu amarah dalam melaksanakan kejahatan dan mengikuti jejak setan. Sedangkan secara lahir, hijrah berarti menghindar dari berbagai fitnah dengan mempertahankan agama. ${ }^{14}$

Beberapa pengertian hijrah sebagaimana tersebut di atas dapat diambil suatu pemahanan bahwa hijrah itu pada dasarnya mencakup tiga aspek. Petama, segala sesuatu yang harus dihindarkan; kedua, segala sesuatu yang harus ditegakkan; dan keiga, segala sesuatu yang

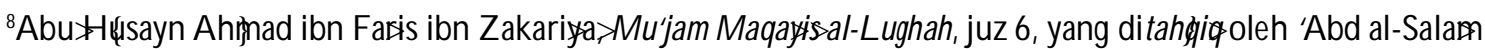
Muhł̧mmad Harun (Beirut: D aæal-Fikr, 1979), 24.

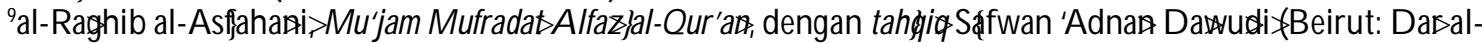
Samiyah, 1992), 354.

${ }^{10}$ Ibid., 534-535.

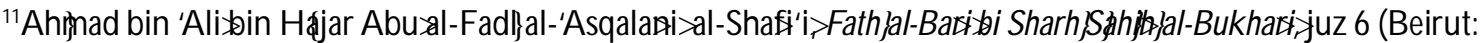
D asal-Ma'rifah, 1379 H.), 190.

${ }^{12}$ Ibid., juz 1, 36.

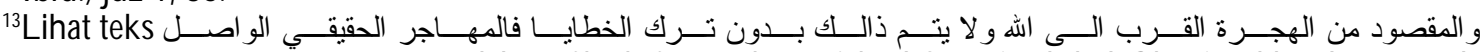

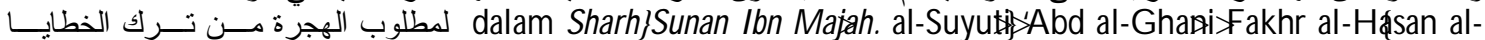
D ahlawi>Sharh,SunanIlonMajah, juz 4 (K hanah: Karatati>t.th.), 350.

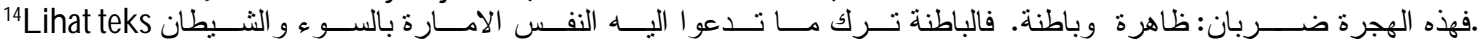

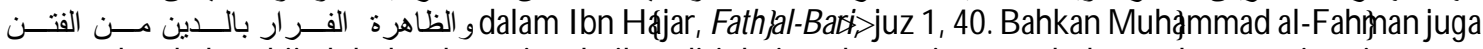
menyatakan bahwa hijrah bukan berarti melarikan diri dari medan perjuangan, bukan pula transmigrasi sematamata dari satu negeri ke negeri lain. Tetapi hijrah ialah pindah dan menjauhkan diri dari bumi yang penuh dengan kemusyrikan, yang diperintah oleh kebodohan dan didominasi oleh kekejaman menuju bumi yang akan memancarkan cahaya kebenaran dan tauhid. Ia adalah suatu revolusi memadamkan kegelapan jiwa, kegelapan kepercayaan, kegelapan masyarakatyang penuh dengan kejahatan dan kerusakan. Lihat Muhł̇mmad al-Fahı̣nan, alWáyal-Isami $\ngtr$ Kuwait: t.p., 1971). 
harus dijalankan secara konsisten dan tidak ke luar dari batas-batas yang telah ditentukan. Secara operasional hijrah dapat dirumuskan sebagai upaya meninggalkan segala kesulitan menuju berbagai kemudahan serta tidak ke luar dari ketentuan yang telah ditetapkan oleh sharisat, baik secara lahiriah mapun batiniah. Atau dengan kata lain bahwa hijrah adalah suatu usaha yang dilakukan oleh seseorang dalam menjauhkan diri dari berbagai bentuk penyimpangan menuju tata aturan secara benar dan konsisten. Di sisi lain, hijrah dalam perspektif historis dapat dimaknai sebagai tindakan pragmatis monumentalis yang di dalamnya juga mencakup nilai-nilai normatif. Karena itu, kajian hijrah tidak cukup hanya dilihat pada dimensi historis romantis monumentalis saja, melainkan harus terisi dengan nilai-nilai normatif yang bersumber pada al-Q ur'an maupun al-Hdith, sehingga tampak dengan jelas adanya integrasi secara holistik dalam bingkai reformulasi epistemologi hijrah dalam dakwah.

\section{Reformulasi Epistemologi Hijrah: Dimensi Normatif}

Reformulasi epistemologi hijrah dalam dimensi normatif ini hanya difokuskan pada lima aspek dasar yang bersumber pada hadith dan beberapa ayat al-Q ur'an, yaitu; a) hijrah dalam pengertian mendekatkan diri kepada Allah Swt., b) hijrah dalam pengertian menjahui larangan Allah Swt., dan c) hijrah dalam pengertian tidak ke luar dari ketentuan Allah. Semua aspek normatif ini akan diintegrasikan dengan nilai-nilai hijrah dalam perspektif historis, sehingga tampak bahwa epistemologi hijrah secara holistik dapat dijadikan sebagai langkah strategis dalam dakwah.

1. Hijrah: Mendekatkan Diri kepada Allah Swt.

Di antara beberapa hądith Nabi yang dapat dijadikan sebagai pijakan dasar tentang hijrah yang berarti mendekatkan diri pada Allah Swt dengan berbagai tuntunan yang diajarkan adalah sebagai berikut.

“Dani Umar bin Khatt;jł r.a bekkata: Rasulullah Saw bersabda: "sesungghnya sahnya sema ambl hanus disetai dengan niat dan sesungghinya suatu peduatan itu tergantung pada niatrya. Barangsiapa hijrah dengan niat karenaAllah dan karema Rasul-Nya maka hijrahnya menuju Allah dan Rasulullah Saw. Dan barang siapa yang hijrah karena mengharapkan dumia atau nanita yang dinikahinya maka pahala hijrahnya sesuai dengan apa yang diniatkanya" 15

Hądith di atas terlihat dengan jelas bahwa hijrah dapat dijadikan sebagai media dan strategi untuk mendekatkan diri pada Allah Swt. Dengan kata lain, hijrah bukan tujuan yang ingin dicapai dalam kehidupan, namun merupakan rangkaian proses untuk mendapatkan predikat hamba terdekat dengan berbagai tuntunan dan petunjuk dari Allah Swt. ('Abd Allah al-Muqarabina). Hal tersebut sudah menjadi ketentuan dan ketetapan Allah Swt yang ingin dicontohkan kepada manusia bahwa untuk mencapai sesuatu harus melalui proses, langkah-langkah dan tahapan-tahapan tertentu.

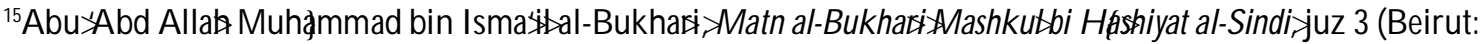
Dazal-Kitab al-Islami>t.th), 238. Pada tempat yang lain, al-Bukharimnenyatakan "sesungguhnya semua amal itu harus disertai dengan niat dan sesungguhnya setiap perbuatan itu tergantung pada niatnya. Barang siapa hijrahnya karena keduniaan atau untuk mengharap perempuan yang dinikahinya maka pahala yang diperolehnya sesuai dengan yang diniatkannya". Ibid., juz 1, 6 .
} 
Urgensi proses dalam mencapai sesuatu yang diharapkan berkorelasi secara signifikan dengan kualitas pencapaian hasil yang akan didapatkan. Bila dalam menjalankan proses dangkal dan pendek, maka akan mencapai hasil tidak begitu jauh dari proses usaha yang diupayakan. Begitu pula sebaliknya, bila dalam melakukan usaha maksimal, tentunya hasil yang akan didapatkan seimbang dengan upaya yang ditempuhnya. Hal tersebut yang diperkuat oleh Shaykh Nawawi al-Bantani dalam kitabnya, TalimalMutáallimbahwa kadar upaya berkorelasi dengan hasil yang akan dicapai (bi cadr al-kadd tuksab al-ma'ali ${ }^{16}$. D engan pemaknaan demikian, maka hijrah ditempatkan sebagai cikal bakal awal untuk mendapatkan sesuatu yang diharapkan. Hijrah menjadi langkah strategis dan syarat utama yang akan menentukan tujuan yang ingin dicapainya.

Imam A bu円 awud dalam riwayatnya telah memperjelas hijrah dengan makna proses. ${ }^{17}$ Artinya hijrah sebagai bentuk proses bertujuan mendekatkan diri pada Allah Swt. Bahkan bila dipahami lebih ekstrim secara tekstual maupun gramatikal, h hdith tersebut menggunakan kata fa laysa min hadhałi shay yang mempunyai arti selain menuju Allah tidak dibenarkan dijadikan sebagai alasan dan tujuan dalam hijrah.

Pemaknaan hijrah sebagai proses untuk mendekatkan diri pada Allah Swt berkonotasi dengan tiga nilai yang akan didapatkan oleh seseorang yang melaksanakan hijrah. Petama, mereka memiliki ketenangan dan ketenteraman jiwa, sebab dengan kedekatan seseorang kepada Allah, ia akan selalu merasa diawasi oleh-Nya, sehingga ia tidak berani menyimpang dari jalan-Nya. Ia juga menjadi yakin bahwa Allah pasti mengetahui segala masalah atau persoalan yang dihadapi. D an kepada hamba yang bertakwa, Allah telah berjanji akan senantiasa memberikan pertolongan, baik dalam bentuk jalan ke luar dari permasalahan yang dihadapi, memberikan rizki yang tak terduga, maupun kemudahan dalam menyelesaikan segala urusan. D engan janji ini, seseorang yang dekat kepada Allah tidak akan risau terhadap kesulitan yang dihadapi dan tidak akan bingung dalam melaksanakan tugas-tugas berat sekalipun. Kedekatan ini juga membuat seseorang senantiasa membiasakan diri untuk berdhikir kepada Allah Swt sehingga memberikan ketenangan dan ketentraman hati. ${ }^{18}$

Kedua, seseorang tidak akan berani menyimpang dari jalan dan ketentuan Allah. Karena dengan kedekatan seseorang kepada-Nya, dia menyadari bahwa apapun yang dilakukannya di dunia pasti dalam pengawasan-Nya. Allah mengetahui sekecil apapun perbuatannya. Apalagi, Allah selalu menempatkan malaikat yang menyertai dan mengawasi manusia guna mencatat segala amalnya, mulai dari niat, ucapan, hingga perbuatannya, sebagaimana yang diisyaratkan dalam al-Q ur'an surah $\mathrm{Q}$ af ayat 17 sampai $18 .{ }^{19}$ Apa yang

\footnotetext{
${ }^{16}$ Nawawi Albantani, Talimil Mutáalim(Surabaya: Darul Maktabah, t.th.), 29.

${ }^{17} \mathrm{Abu} \gg$ arud Sulayman ibn al-'Ash'ath al-Sijistaxisl-Azdi>SunanAbuĐaxud, juz 6 (Suriyah: D asal-Hadith, t.th.), 118. Iman A bu円 awud pada bab atau kitabal-tłalaqdan al-adblbmeriwayatkan bahwa "Rasulullah Saw. bersabda: sesungguhnya semua amal itu harus disertai dengan niat dan sesungguhnya setiap perbuatan itu tergantung pada niatnya. Barang siapa hijrahnya karena keduniaan atau mengharap perempuan untuk dinikahinya maka pahala yang diperolehnya sesuai dengan yang diniatkannya ". Ibid., 83. Lebih lanjut Abu¥ awud menegaskan bahwa "jika hijrah itu benar-benar karena Allah, maka semua tujuan selain daripada-Nya adalah tidak termasuk kategori hijrah". Lihat Ibid., juz 12, 118.

${ }^{18}$ al-Qur'an, 13 (al-Ra'd): 28.

19"[Yaitu] ketika duamalaikatmencatatamal pedouatannya, yangsatududuk di sddahk kanan danyanglainduduk di sdbdah kin. Tiadasuatuucapan punyangdiucapkannya mainkanadadi dkkatrya malaikat pengawasyangsdalu hadir". Lihat alQur'an, 50 (Qaf):17-8.
} 
telah dicatat oleh malaikat dan diawasi oleh Allah atas perbuatan manusia, maka dia harus berani mempertanggungjawabkan. Sehingga manakala di dunia dia berbuat baik, maka kebahagiaan akan diperoleh dan bila dia berbuat buruk, maka kesengsaraan harus dirasakan.

Ketiga, bertanggungjawab terhadap tegaknya nilai-nilai Islam. Perjuangan menegakkan ajaran Islam di muka bumi merupakan keharusan yang mesti ditunaikan oleh setiap manusia sesuai dengan kemampuan dan kapasitas masing-masing. Kedekatan diri kepada Allah akan membuat seseorang merasa terkontrol langsung oleh Allah. Sehingga, kalau perjuangan itu tidak dilaksanakan, membuatnya dinilai sebagai orang yang tidak konsekuen dengan ke-islaman-nya. Dari sini lahir sikap bertanggungjawab terhadap tegaknya nilai-nilai Islam, yang pada gilirannya membuat seseorang selalu berusaha dan berjuang dalam penegakkan ajaran Islam sendiri, meskipun hanya seorang diri. Karena itu, Allah menegaskan tentang perbedaan antara orang yang berjihad dengan orang yang tidak berjihad dalam al-Q ur'an surah al-Nisa`ayat $95{ }^{20}$

D engan demikian, menjadi sangat jelas bahwa mendekatkan diri kepada Allah Swt dalam terminologi hijrah merupakan sesuatu yang amat penting dalam kehidupan masyarakat muslim. Sebab, tanpa kedekatan dengan Allah Swt, umat manusia terasa sangat sulit akan berubah menjadi lebih baik. O leh karena itu, segenap manifestasi dari berbagai aktifitas umat manusia, baik dalam bentuk ibadah ritual (mahtoh) maupun sosial (mramalah), harus ditujukan dalam kerangka "mendidik diri untuk selalu dekat kepada Allah Swt."

2. Hijrah: Menjahui Larangan Allah

Bentuk larangan Allah dalam perspektif hądith diformulasikan dalam wujud dan teknik yang berbeda antara yang satu dengan lainnya. Namun semua wujud dan bentuk larangan tersebut masih dalam pengertian hijrah menjahui larangan Allah, baik dari kejelekan, meninggalkan kesalahan maupun dosa, meninggalkan berbagai larangan hingga meninggalkan berbagai bentuk pelanggaran yang haram. Beberapa hądith yang dimaksud akan diuraikan berikut.

a. Hijrah dari Kejelekan

Di antara beberapa $h$ dith yang menjelaskan hijrah dalam pengertian meninggalkan kejelekan adalah sebagai berikut.

"Nabi Muhammad Saw bersaboda:"orang mikmin adblah orang yang bisa dipercaya manusia dan orangmisimadalah arangyang bisa menydamatkan msimlainnya dani bahaya lisan dan tangannya (kemampuan maupun kkxuasaamya) Dan orangyanghijrah yaitu orangyangpindah dari kejddkan atau kesalahan Demi Dzat yang menguasai jiwaku dangan kekuasaan-Nya, tickk akan masuk surga hamba yang tickk membei keamanan kepada tetangga dkkatuna". ${ }^{21}$

\footnotetext{
20،Tidaklah samaantara orangmikminyangduduk [tidak tunumberperangl, yangtidak mempunjai uzur, dengan arangyang bejihaddi jalanAllahdenganharta danjiva medka". Lihat al-Q ur'an, 4 (al-Nisał: 95.

${ }^{21}$ Ahminad ibn H Ahmoad juga meriwayatkan bahwa 'Zaid Ibn al-H «ibab menceritakan kepadaku, Musałoin 'Aliæmengkabarkan bahwa saya mendengar ayahku berkata saya mendengar 'Abd Allah bin Amr bin 'As \$mendengar Rasulullah Saw. bersabda: siapakah orang muslim itu? mereka menjawab Allah dan Rasul-Nya yang lebih tahu. Nabi Muhammad Saw. kemudian bersabda: "Sesungguhnya orang muslim itu ialah orang yang bisa menyelamatkan dari lisan dan tangannya. Rasul bertanya lagi: Siapa orang mukmin itu? mereka menjawab: Allah dan Rasul-Nya yang lebih tahu. Nabi Muhammad Saw. kemudian bersabda: O rang mukmin adalah orang yang bisa menyelamatkan sesama mukmin dari jiwa dan harta mereka. D an orang yang hijrah itu orang yang hijrah dari kejelekan maka tinggalkanlah kejelekan tersebut". Ibid., 259.
} 
Hą̧dith di atas memberikan penjelasan bahwa hijrah bermakna meninggalkan perilaku tercela dalam pandangan agama Islam. Sebagai agama, Islam memberikan pijakan dan aturan kepada umat manusia untuk membangun kehidupan yang dilandasi nilai-nilai terpuji, jauh dari perilaku tercela. Bahkan kata hijrah dalam hądith di atas disandingkan dengan kata Islam dan Iman. Seolah-olah hądith tersebut menegaskan bahwa keabsahan seseorang menjadi muslim dan mukmin tidak hanya dengan lima rukun Islam dan enam rukun Iman, namun berdampingan dengan seperangkat kekuasaan dan kemampuan dalam menjaga dan menyelamatkan lisan dan kedua tangannya dari perilaku kejelekan. D engan arti demikian, hijrah lebih terfokus pada kemampuan seorang muslim dan mukmin dalam mengartikulasikan posisinya sebagai manusia yang senantiasa berinteraksi, berintegrasi dan bersinergi dengan manusia lainnya secara damai dan penuh kasih sayang, sebagaimana tercermin dalam hädith Nabi Saw yang menggambarkan interaksi kehidupan orang-orang mukmin yang satu sama lainnya dengan penuh cinta dan kasih sayang.

"Rasulullah Sawbersabca: Engkau tdah menyaksikan orangorang mikmin dalaminteraksinya yangpenuh dengan aita, kasih sayangdankeakrabannya bagaikan kesaturantubuhyangmanakala satu d antaranya sakit, maka dapat menembus pada sdunuh anggta yang lain untuk ikut bejjaca dan merasakan pendenitaannya". ${ }^{22}$

Selanjutnya, dari mata rantai kalimat-kalimat hædith yang mengawali makna hijrah untuk meninggalkan perilaku kejelekan, seorang mukmin dan muslim mampu memberikan rasa aman terhadap harta dan jiwa khususnya, keluarga dan tetangga terdekat serta masyarakat luas pada umumnya.

b. Hijrah dari Kesalahan dan Dosa

Terdapat beberapa h dith yang menjelaskan hijrah dalam pengertian meninggalkan kesalahan dan dosa, yang antara lain dinyatakan:"Sesungguhnya Nabi Saw besabda: arang mikmin adklah arang yang membei keamman harta dan jïu manusia, sedangkan mikajir adblah arang yang meriggalkan kesalahan dan dbsa". ${ }^{23}$

Fitrah manusia tidak bisa lepas dari salah dan dosa. Pemaknaan demikian memberikan pemahaman bahwa tidak ada satupun manusia yang bisa menghindar dari salah dan dosa. Oleh karena itu, hijrah dengan bersandar pada hłgdith tersebut bermakna meninggalkan kesalahan dan perilaku dosa. Pemaknaan demikian bukan berarti menegaskan fitrah manusia, namun menganjurkan agar perbuatan salah dan dosa tidak dilakukan secara sengaja, terus menerus (mudawamah) atau ketika mengetahui bahwa perbuatan yang dilakukan tergolong perbuatan dosa, sesegera mungkin bertobat dan berniat tidak mengulangi perbuatan menyimpang dan dosa tersebut.

\footnotetext{
${ }^{22 a l-B u k h a x i>M a t n a l-B u k h a x i>j u z ~ 4, ~} 60$.

${ }^{23} A$ bu円 awud, SunanAbuĐaxud juz 6, 119. Sejalan dengan hågdith di atas, Imam A hinad juga meriwayatkan "Rasulullah Saw. bersabda pada waktu haji Wada' perkenankanlah aku kabarkan kepadamu bahwa orang mukmin adalah orang yang bisa memberi keamanan kepada sesama manusia atas harta dan jiwanya. Dan orang muslim ialah orang yang bisa menyelamatkan dari lisann dan tangannya. O rang yang berjihad atau berjuang yaitu orang yang menyerahkan dirinya (jiwanya) untuk taat kepada Allah (dalam ketaatan kepada Allah) dan orang yang hijrah ialah orang yang berpindah dari kesalahan dan dosa". Lihat A himad bin Hæanbal, Musnadal-ImamA himadbin Hanbal, juz 4, 276.
} 
Hądith tersebut pada intinya memberikan gambaran bahwa kehidupan sosial manusia tidak bisa dilepaskan dari aneka ragam ketegangan dengan manusia lain terutama berkaitan dengan harta (dunia). Tidak jarang ditemukan, bahwa harta menjadi cikal bakal rusaknya hubungan persaudaraan, hubungan ayah dengan anak dan hubungan persahabatan. Hal demikian, dalam konsep agama Islam merupakan perilaku yang mendatangkan kerusakan dan menghancurkan cita-cita kehidupan damai dan sejahtera. Oleh karena itu, seorang mukmin dan muslim dalam berhijrah harus rela meninggalkan perilaku kejelekan terutama yang bersumber dari hawa nafsu yang menyimpang maupun yang berhubungan dengan masalah harta yang dimiliki oleh orang lain. Penjelasan mengenai hijrah dalam pengertian meninggalkan kesalahan dan dosa dapat dibedakan menjadi beberapa hal, yaitu: hijrah dalam pengertian meninggalkan larangan Allah dan meninggalkan yang haram.

c. Hijrah dari Larangan Allah

Fokus makna hijrah yang terkait dengan masalah teknik meninggalkan larangan Allah telah dijelaskan dalam hądith yang diriwayatkan oleh Imam Bukhari berikut. "Dari Abdullah ibn Amr ra menceitakan dari Nabi Muhammad Sawbersaboba arangmusim adalah arang yang bisa menydamatkan muslim lainnya dari bahaya lisan dan tangannya (kemampuan maupun kekuasaannya) dan orangyang hijrah yaitu orangyang pindah dan apa saja yang tdah dilarang deh Allah Sut."24

Hądith di atas menegaskan bahwa kesempurnaan seorang muslim akan menjadi kenyataan apabila mereka telah memiliki kemampuan untuk meninggalkan larangan Allah terutama yang berkaitan dengan perilaku aniaya terhadap umat Islam lainnya. D engan demikian, mereka akan senantiasa berada pada posisi kebaikan dengan mewujudkan semua aspek yang diperintahkan oleh Allah kepadanya. ${ }^{25}$

d. Hijrah: Meninggalkan yang Haram

Hijrah terbaik dari beberapa hạdith yang terkait dengan hijrah dalam pengertian meninggalkan larangan adalah hijrah meninggalkan yang haram. Berikut ini adalah beberapa hądith yang dimaksudkan.

\footnotetext{
${ }^{24}$ al-Bukhaxi>Matnal-Bukhari>juz 3, 8. Senada dengan hạdith yang menekankan makna hijrah dengan teknik meninggalkan larangan Allah, juga dijelaskan pada halaman dengan jalur riwayat yang berbeda oleh Imam alBukhaki>yakni "Nabi Muhammad Saw. bersabda: orang muslim adalah orang yang bisa menyelamatkan muslim lainnya dari bahaya lisann dan tangannya (kemampuan maupun kekuasaannya) dan orang yang hijrah yaitu orang yang pindah dari apa saja yang telah dilarang oleh Allah Swt." Ibid., juz 4, 34. Teks hądith yang dimaksudkan

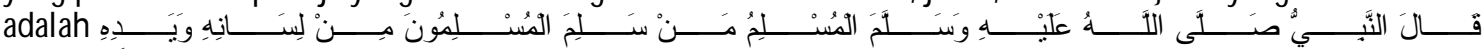

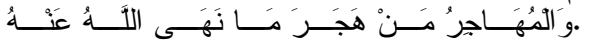

${ }^{25}$ D engan kata lain bahwa Islam memang diturunkan oleh Allah Swt kepada umat manusia dengan seperangkat aturan yang bertujuan mengantarkan manusia menemukan kebahagiaan di dunia maupun di akhirat. Seperangkat aturan tersebut meliputi perkara yang wajib dilaksanakan baik berupa perintah maupun larangan. Kewajiban melaksanakan perintah pada satu sisi yang harus diwujudkan, namun perintah pada sisi yang lain merupakan larangan untuk ditinggalkan. Artinya antara perintah yang harus dilaksanakan dan perintah yang harus ditinggalakan hanya dibatasi oleh garis yang sangat tipis. Bila melaksanakan shalat adalah kewajiban, maka meninggalkan shalat

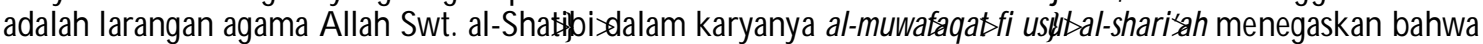
tujuan perintah pada dasarnya adalah untuk diwujudkan dengan maksud agar manusia senantiasa tetap berada di dalam garis dan ketentuan syariat. Sedangkan tujuan larangan pada substansinya adalah untuk ditinggalkan dengan maksud agar manusia tidak terjerat maupun terjebak oleh berbagai belenggu hawa nafsal-ammatah Lihat

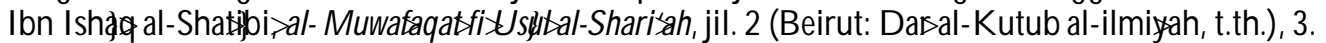


“Dari Abodillah bin Habsi ral-Khatami bahwa Nabi Saw ditanya: amal apakah yang paling utama? Nabi mejanab a ukup lama dalammdaksanakan słalat. Kemudan sadaqah apa yang paling beiik? Jawab Nabi, kesungguhan dalam memanfaatkan sesuatu yang sedikit. Kemudian Nabi ditanya lag, hijrah apa yang palingutama, nabi merjawab yaitu arangyang behijrah dari segala sesuatu yang diharankan deh Allah". ${ }^{26}$

Sehubungan dengan terminologi hijrah, maka hądith di atas menunjukkan bahwa hijrah yang paling utama adalah berpindah dari sesuatu yang diharamkan. Sudah barang tentu perpindahan tersebut mengarah pada perbaikan kualitas maupun kuantitas sumber daya dengan berbagai aspek dan dimensinya.

3. Hijrah dalam Limitasi Allah

Aspek hijrah yang terpenting selain meninggalkan berbagai penyimpangan dan menyambung berbagai kebaikan adalah melanggengkan segala kebaikan dengan segala bentuknya dan tidak sampai melintasi batas-batas yang telah ditetapkan oleh sharigat Islam. Kelanggengan dalam menegakkan berbagai kebaikan tersebut justru disertai dengan berbagai usaha, perjuangan dan perencanaan yang kuat dan mantap untuk menghindarkan diri dari berbagai musuh, belenggu maupun kesulitan-kesulitan, sebagaimana yang diisyaratkan dalam hạditith di bawah.

“Diniwayatkan dari Ilon Abbas ra. Ia berkata: bahwa Rasulullah Saw tdah bersabda: Tidak ada hijrah setdah kemenangan Islam tetapi yang ada hanya jihad (pejuangan) dan niat (untuk merjauhkan din dari betbagai msuh dengan segala bertuknya). Dan apabila anda diperintahkan dehimamuntuk keluar bejuangdan mdaksanakan amal baik lainnya, maka laksanakanlah ${ }^{27}$

Secara historis, al-K hattgajbi dan lainnya mengatakan bahwa hijrah menuju Madinah pada permulaan Islam memang diwajibkan dan benar-benar sangat diperlukan untuk memperkuat umat Islam. Akan tetapi setelah Fath/Makkah (kemerdekaan Islam di Makkah) yang disertai dengan sejumlah masyarakat yang masuk Islam secara berbondongbondong, maka hijrah ke Madinah menjadi tidak wajib, melainkan yang wajib adalah jihad dan niat untuk menjauhkan diri dari musuh dengan segala bentuknya.

\footnotetext{
${ }^{26} \mathrm{~A}$ bu円 awud, SumanAbuĐaxud, juz 4, 60. Konteks hijrah pada hadith di atas menunjukkan bahwa hijrah yang terbaik menurut Nabi Saw. adalah meninggalkan segala sesuatu yang diharamkan. Bahkan hadith tersebutdikuatkan

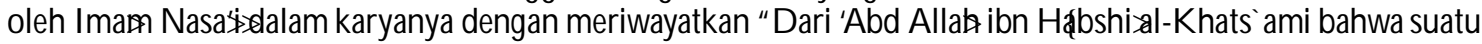
ketika Nabi Saw. pernah ditanya: amal apakah yang paling utama? Nabi menjawab, yaitu; iman yang sempurna yang di dalamnya sama sekali tidak mengandung keraguan, kemudian jihad di jalan Allah tanpa adanya sedikitpun kejengkelan, kemudian haji yang mabrur. Nabi ditanya lagi, salat apa yang paling utama. Nabi menjawab, yaitu, salat yang cukup lama dalam kekhusyukannya. Rasul ditanya lagi, sadaqah apa yang paling baik? Jawab Nabi, kesungguhan dalam memanfaatkan sesuatu yang sedikit. Kemudian Nabi ditanya lagi, hijrah apa yang paling utama, Nabi menjawab, yaitu orang yang berhijrah dari segala sesuatu yang diharamkan oleh Allah Azza wajalla".

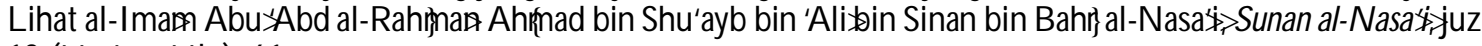
13 (t.t.: t.p., t.th.), 61.

${ }^{27}$ al-Bukhaxi> Matnal-Bukhaxi,juz 3, 56. Lihat juga hădith "D iriwayatkan dari Khalid, dari Abu>Uthman al-Nahdi> dari Mujashiłn Mas'ud berkata: Mujashiælengan saudaranya Mujakid ibn Mas'ud datang kepada Nabi Saw. seraya mengatakan: Ini Mujakid ingin baiat terkait dengan hijrah. Nabi menjawab: Tidak ada hijrah setelah kemenangan Islam, tetapi saya membaiatnya untuk selalu komitmen dengan Islam hingga akhir hayat" dalam Ibid, juz 3, 57. Selain itu, Imam Ahinad meriwayatkan "dari Utsman, dari Mujashiłbn Mas'ud berkata: Saya bertanya kepada Rasul Saw.. Ya Rasulallah! Ini Mujałid ibn Mas'ud ingin baiat terkait dengan hijrah. Nabi menjawab: Tidak ada hijrah setelah kemenangan Islam, tetapi saya membaiatnya untuk selalu komitmen dengan Islam (hingga akhir

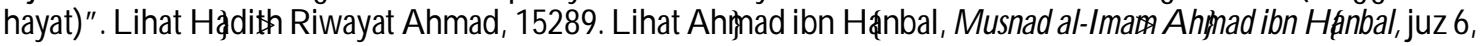
334.
} 
Lebih lanjut, kewajiban hijrah sebelum fath/makkah sebagaimana dijelaskan dalam kitab Fath/al-Bari diklasifikasikan menjadi tiga kelompok. Petam, mereka mempunyai kemampuan hijrah, tetapi tidak mampu menyebarkan agama, serta tidak mampu melaksanakan kewajiban, maka hijrah wajib dilakukan. Keetua, mampu hijrah, masih memungkinkan untuk menyebarkan agama dan melaksanakan kewajiban, maka masih dianjurkan dan masih lebih baik untuk memperluas umat Islam setempat. Ktica, tidak memiliki kemampuan untuk hijrah, karena menjadi tawanan perang, atau sakit atau karena gangguan lainnya, maka diperkenankan untuk tinggal di tempat semula. Namun apabila mereka selalu berusaha untuk tetap melaksanakan hijrah maka mereka akan lebih baik dan akan memperoleh pahala yang lebih besar.

\section{Reformulasi Epistemologi Hijrah: Dimensi Historis}

Hijrah adalah peristiwa historis yang dicatat sebagai awal dari munculnya Islam sebagai agama dengan etos sosial yang mencitapkan masyarakat egaliter dan demokratis. Pasca peristiwa hijrah itulah Nabi Muhammad Saw melakukan langkah-langkah spektakuler dalam membentuk peradaban umat manusia yang dimulai dari kota Madinah. Yang dimaksud hijrah dalam sejarah Islam adalah peristiwa pindahnya Nabi Besar Muhammad Saw dari kota Suci Mekkah ke Madinat al-Munawwarah. Perpindahan ini dimaksudkan untuk memenuhi permintaan masyarakat Madinah sendiri, sebuah kota yang sebelumnya bernama Yathrib. Penduduk kota ini selalu berada dalam kondisi percekcokan antar suku yang terus menerus.

Dalam pandangan para orientalis, hijrah Nabi ini dianalisis secara kritis, dengan perkembangan presepsi mereka dari bentuk pandangan negatif sampai ke bentuk pandangan positif. Alfred Guillamme, umpamanya, dalam bukunya Islammenyebut hijrah itu dengan exile(pengusiran). Montgomery Watt dalam bukunya Muhammadat Meccamenyatakan bahwa hijrah itu adalah emigation (perpindahan). Demikian pula Philip K. Hitti dalam bukunya Isamic Way of Life, menerjemahkan kata hijrah tersebut dengan the scheme of migation (perpindahan yang berencana); dan akhirnya Bernard Lewis menyebut hijrah dengan revdution (perubahan radikal). Agaknya tidak berlebihan bila Michel Hart, dalam bukunya Seratus Tokoh, menempatkan nama Nabi Muhammad pada peringkat pertama tokoh dunia yang paling berhasil. Bagi umat Islam, diperlukan upaya penggalian kembali makna hijrah ini dalam memasuki Alam Baru (Millenium Baru), untuk menemukan semangat baru yang tercakup di dalamnya.

Millenium Baru adalah era kompetisi besar-besaran. Siapa yang tidak berhasil ke luar sebagai pemenang dalam kompetisi itu, jangan marah bila dipinggirkan oleh pihak lain. Bahkan bukan hanya dipinggirkan, mungkin juga tergilas oleh kemajuan dalam proses kompetisi itu sendiri. Hanya bangsa dan umat yang berkualitas yang bisa ke luar sebagai pemenang dari arena kompetisi besar-besaran itu. Umat yang berkualitas tersebut diistilahkan oleh al-Q ur'an dengan istilah khayr ummah(sebaik-baik umat), yang dimunculkan ke pentas sejarah peradaban umat manusia. Inilah yang difirmankan oleh Allah dalam al-Q ur'an 3 (Ali Imran): $110 .^{28}$

${ }^{28}$ Yakni "Kamu adalah umat yang terbaik yang dilahirkan (ke pentas sejarah, pen.) untuk manusia,(supaya) menyuruh kepada yang ma'ruf, dan mencegah dari yang munkar, dan beriman kepada Allah. Sekiranya ahli kitab beriman, tentulah itu lebih baik bagi mereka, di antara mereka ada yang beriman, dan kebanyakan mereka adalah orang-orang yang fasik". Lihat al-Q ur'an, 3 (Ali Imraß): 110. 
D engan predikat sebagai khayraummahitulah, Marshal G oodwin Simms Hodgson, seorang orientalis yang begitu apresiatif terhadap Islam, dalam bukunya TheVeture of IsamConiene and History in a World Civilization berkomentar: "bahwa orang-orang Islam telah mengambil ramalan ini dengan serius, sampai-sampai mencoba untuk membentuk sejarah seluruh dunia sesuai dengan isi ramalan tersebut" ${ }^{29}$ Lebih lanjut, Hodgson mengatakan: segera setelah kepercayaan dibangun, kaum muslimin telah berhasil mewujudkan sebuah bentuk masyarakat baru, yang dengan pergeseran waktu membawa serta lembaga-lembaganya sendiri yang khas, seperti seni dan sastranya, ilmu dan kesarjanaannya, bentuk politik dan so sialnya, seperti juga sistem peribadatan dan kepercayaannya, semuanya memberi kesan yang islami. ${ }^{30}$

Seiring dengan pondasi potensial sbagaimana tersebut di atas, maka setelah melakukan hijrah, Nabi Muhammad Saw dapat membangun masyarakat Madinah lima belas abad yang lalu. Sejarah mencatat bahwa karakter masyarakat Madinah dengan pimpinan Rasulullah adalah termasuk kategori plural, multi-etnis, multi-agama, bahkan masyarakatnya dapat dipersatukan oleh Nabi dengan satu commonplatformMithacal-Madinahatau Piagam Madinah. ${ }^{31}$

Sejarah juga mencatat bahwa Nabi Muhammad Saw telah mengukir berbagai prestasi kemanusiaan dengan membangun masyarakat berpradaban. Prestasi inilah yang menurut Rober N. Bellah dalam bukunya Beyond Beief dicatat sebagai tindakan loncatan jauh ke depan dalam kecanggihan sosial dan kapasitas politik. ${ }^{32}$ Lebih lanjut, Bellah mengomentari hal itu dengan mengatakan: Tatkala struktur yang telah terbentuk di bawah Nabi dikembangkan oleh para khalifah pertama untuk menyediakan prinsip penyusunan suatu imperium dunia, hasil sesuatu yang untuk masa dan tempatnya yang sangat modern. Ia modern dalam hal tingginya tingkat komitmen, keterlibatan dan partisipasi yang diharapkan dari kalangan rakyat jelata sebagai anggota masyarakat. Ia modern dalam hal keterbukaan kedudukan kepemimpinannya untuk dinilai kemampuan mereka menurut landasan-landasan universalistas dan dilambangkan dalam upaya melembagakan kepemimpinan yang tidak bersifat turun temurun. ${ }^{33}$

Prestasi-prestasi gemilang itulah yang dicapai oleh Nabi Muhammad Saw., yang beliau peroleh setelah peristiwa hijrah. Betapa tidak, dari suasana dikejar-kejar untuk tugas dakwah di kota Mekkah selama 13 tahun, akhirnya menjadi penguasa masyarakat Madinah selama 10 tahun. Dan ketika Nabi wafat, setelah menaklukkan Makkah, hampir seluruh Jazirah Arabia berada di bawah kekuasaan Madinah. Bahkan setelah pemerintahan Abu Bakar alSilddiø sebagai khalifah pertama dan Umar bin Khattab sebagai khalifah kedua, kawasan

\footnotetext{
${ }^{29}$ Marshal G.S. Hodgson, The Venture of Islam: Concience and History in a World Civilization (Chicago: The University of Chicago Press, 1974), 71.

${ }^{30}$ Kesan ini dapat dipahami dari teks aslinya yang berbunyi Soonsafter thefaunding of thefaith, Musimsucceetedin buildinga nevform of soidy, wich in timecamied with it its oun distindiveinstitutions, its art and literature, its seienceand schdarship, itspolitical and soial forms, as well asit alt andceed, all beaningandunmistakableIslamicimpress Lihat Ibid., 71.

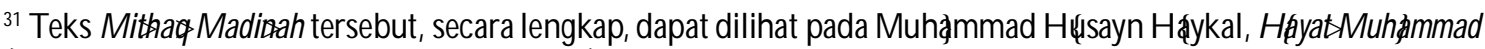
(Kairo: Maktabat al-Nahdąh al-Misisiyah, 965), 225-227. Karya ini telah diterjemahkan ke dalam bahasa Indonesia oleh A hmad Sukarja. Lihat Ahmad Sukarja, PiagamMadinahdanUndang UndangDasar 1945 (Jakarta: UI Press, 1995), 47-57.

${ }^{32}$ Robert N. Bellah, BejonBdie, disebut dalam Nurcholish Madjid, IdamAgama Kemanusiaan: Merbangun Taradisi dan Visi Baru Indonesia (Jakarta: Yayasan Wakaf Paramadina, 1995), 15.

33ibid.
} 
yang disebut sebagai daerah pusat peradaban manusia, yaitu daerah-daerah Shiria, Mesir dan Persia dan kemudian meluas ke sebelah Barat sampai ke A tlantik, dan ke sebelah Timur sampai ke Gurun Gobi, telah dikuasai oleh kaum Muslimin.

Berbagai perestasi gemilang yang telah dicapai sebagaimana diungkapkan di atas menunjukkan betapa besar dan luasnya cakupan makna epistemologi hijrah dalam perspektif historis, terutama dalam kancah dakwah dan pengembangan masyarakat multikultural. Karena itu, epistemologi hijrah dengan berbagai konsekuensinya tidak hanya berkutat pada romantika monumental masa lalu belaka, tetapi semangat dan nilai-nilai epistemologi hijrah tersebut dapat dikembangkan untuk masa sekarang dan masa-masa yang akan datang.

\section{Integrasi Epistimologi ${ }^{34}$ Hijrah dalam Dakwah}

D akwah sebagaimana yang dipahami oleh banyak kalangan adalah ajakan atau seruan untuk menciptakan suasana damai dan tenteram serta penuh kesejukan. Ia merupakan ajakan untuk memahami dan melaksanakan nilai-nilai Islam dalam kehidupan nyata. Ada proses merubah atau memindahkan situasi masyarakat yang tidak menggembirakan kepada situasi yang menggembirakan, dari masyarakat yang sering tawuran kepada masyarakat yang cinta damai dan melaksanakan perdamaian itu secara nyata dan konkrit. D alam buku Tadhkirat al-Du'at, al-Bahi>al-Khuli>menjelaskan bahwa dakwah itu adalah "upaya memindahkan manusia dari satu situasi kepada situasi yang lebih baik" ${ }^{35}$

Dakwah memang berinti pada pengertian menghasung atau menyeru manusia untuk berbuat kebajikan dan menghindarkan diri dari keburukan, demi tercapainya kebahagiaan dunia dan akhirat. ${ }^{36}$ Seruan tersebut dilakukan dengan cara yang lemah lembut dan menyejukkan. D an itu dilakukan dengan tujuan untuk tegaknya agama Islam dan berjalannya sistem Islam dalam kehidupan individu, keluarga dan masyarakat. Atau dengan kata lain dakwah sebenarnya bertujuan "menghidup dan memberdayakan", sehingga masyarakat

\footnotetext{
${ }^{34}$ Prinsip utama yang dijadikan landasan integrasi ilmu didasarkan pada konsep "Tauhid". Menurut Mulyadhi Kartanegara, konsep ini diambil dari formula konvensional Islam LailakaillaAllahyang artinya "tidak ada tuhan melainkan Allah". Menurutnya, konsep ini telah menjadi prinsip paling dasar dari ajaran Islam, dan dalam kaitannya dengan concem tentang integrasi ilmu, maka konsep ini telah menjadi prinsip yang paling utama dari prinsip-prinsip epistemologi Islam, sehingga ia juga telah menjadi asas pemersatu atau dasar integrasi ilmu pengetahuan manusia. Lihat Mulyadhi Kartanegara, Integasi Ilmi: SeduahRdkonstruks Hdistik (Bandung: Arasy Mizan, 2005), 32. Secara teknis M. Amin Abdullah mencontohkan tentang kepemilikan agama tertentu oleh seseorang (havingareligion) dan keberagamaan manusia pada umumnya (reigiosity) adalah sangat berbeda secara intelektual. Keduanya tidak perlu dipertentangkan, melainkan menuntut perpaduan. Menurutnya, keberagamaan manusia pada umumnya bersifat universal, transendental (tidak terbatas, tidak tersekat-sekat, transhistoris (melewati batas-batas pagar historisitas-kesejarahan manusia), namun religiusitas yang begitu mendalam-abstrak, pada hakekatnya tidak dapat dinikmati oleh manusia tanpa sepenuhnya terlibat dalam bentuk religiusitas yang kongkret, terbatas, tersekat, historis, terkurung oleh ruang dan waktu tertentu secara subyektif. Kedua dimensi religiusitas tersebut menurut penulis mempunyai hubungan yang bersifat dialektis, dalam arti saling mengisi, melengkapi, memperkokoh, memanfaatkan, bahkan juga saling mengkritik dan mengontrol. Hubungan antara keduanya dapat diumpamakan seperti hubungan antara puresience(ilmu-ilmu dasar) dan appliedsciene(ilmu-ilmu terapan). Lihat M. Amin Abdullah "Dialektika Agama antara Profanitas dan Sakralitas" dalam Moh. Shofan, JalanKetiga PenikiranIdam(Yogyakarta: IRCiSoD , 2006), 7. Sehubungan dengan konsep tersebut, maka semangat historisitas hijrah dapat diintegrasikan dengan normativitas hijrah sebagaimana tersebut dalam ajaran hądith maupun alQur'an.

${ }^{35}$ al-Bahi $x \mathrm{l}-\mathrm{K}$ huli>Tadhkirat al-Du’at(Mesir: D aæal-Kitab al-'Arabi>1952), 27. Lihat juga M. Quraish Shihab, MerbumikanAl-Quran(Bandung: Mizan, 1992), 194.

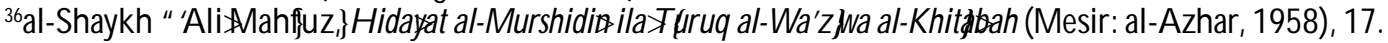


memperoleh momentum untuk meningkatkan taraf hidup dan kesejahteraan, serta menimbulkan suasana baru yang kondusif bagi tegaknya nilai-nilai agama, sebagaimana ditegaskan oleh Allah dalam al-Qur'an surah al-Anfab ayat $24 .{ }^{37}$

Dakwah kalau demikian, pada hakikatnya adalah panggilan Allah dan Rasul beserta para penganutnya, sebuah panggilan yang membawa kepada yang menghidupkan. Atau dengan kata lain panggilan untuk memberdayakan. "Bukan panggilan yang merugikan, tetapi panggilan kepada kehidupan lahir batin, maju setingkat demi setingkat menuju kemenangan dan kejayaan." ${ }^{38}$

D alam rangka melakukan reaktualisasi epistemologi hijrah dalam dakwah, maka tindakan pertama yang patut disadari adalah bahwa masyarakat yang dibangun oleh $\mathrm{Nabi}$ itu adalah masyarakat peradaban, masyarakat divility, atau dengan kata lain masyarakat yang beradab, yaitu masyarakat yang adil, terbuka dan demokratis dengan landasan iman dan taqwa kepada Allah Swt. Keimanan dalam hal ini bisa dimaksudkan sebagai nilai-nilai yang mendasari tindakan hijrah, yang selanjutnya dapat diidentikkan pada nilai-nilai normatif yang sesungguhnya adalah sangat tergantung pada seberapa besar kapasitas dan standar kompetensi pengetahuan seseorang terhadap seperangkat ajaran dasar tentang hijrah. Sedangkan, terma ketaqwaan kepada Allah bisa dimaksudkan sebagai bentuk manifestasi hijrah yang dilandasi oleh nilai-nilai keimanan maupun kesadaran seseorang. D engan demikian, ketika seseorang menyebut dimensi iman, sesungguhnya adalah sudah berintegrasi dengan perwujudannya. D emikian pula penyebutan tentang ketakwaan, sesungguhnya adalah sudah berintegrasi dengan nilai-nilai yang mendasarinya.

Alhasil, pemahaman hijrah secara terpadu antara nilai-nilai normatif dan historis dalam sebuah konsep holistik sudah menjadi keharusan untuk dijadikan sebagai langkah strategis dalam dakwah, pada saat kapan, di mana dan oleh siapa saja yang mewujudkan tugas dan tujuan dakwah. Bahkan tindakan apa saja seakan dapat mengacu pada formulasi hijrah dengan berbagai dimensi dan aspek kehidupan umat manusia. Karena sesungguhnya hijrah itu sendiri selain mencakup tata nilai dan aturan mulai dari bagaimana tata aturan untuk meninggalkan sesuatu yang tidak berkenan, bagaimana strategi untuk mewujudkan impian yang terbaik, dan bagimana tata kelola untuk mengabadikan segala sesuatu yang dicitacitakan. Bahkan manifestasi hijrah juga telah terbukti dalam sejarahnya bahwa momentum hijrah mampu mengubah tatanan masyarakat yang tertinggal menuju masyarakat majmuk, kompetitif, berperadaban dan berprestasi gemilang. Oleh karena itu, makna hijrah dan implementasinya tidak terbatas dan bahkan tidak hanya terkesan dalam pengertian monumental romantis belaka, melainkan terpadu dengan nilai-nilai normatif secara simultan dan konprehensif yang dapat dilaksanakan pada saat kapan saja, di manapun keberadaannya dan oleh siapapun yang berkenan mewujudkan tugas-tugas dan tujuan dakwah.

\footnotetext{
37"Hai orang-orang yang beriman, penuhilah seruan Allah dan seruan Rasul apabila Rasul menyeru kamu kepada suatu yang memberi kehidupan (rohani dan jasmani) kepada kamu ketahuilah bahwa Sesungguhnya Allah membatasi antara manusia dan hatinya dan Sesungguhnya kepada-Nyalah kamu akan dikumpulkan". Lihat alQ ur'an, 8 (al-Anfaß): 24. Maksud ayat ini selain menyeru kamu berperang untuk meninggikan kalimat Allah yang dapat membinasakan musuh serta menghidupkan Islam dan muslimin. juga menyeru kamu kepada iman, petunjuk jihad dan segala yang ada hubungannya dengan kebahagiaan hidup di dunia dan akhirat. Karena Allahlah yang menguasai hati manusia.

${ }^{38}$ Mohammad Natsir, FiqhudDakwah: Jgjak RisalahdanDasar-DasarDakwah (Jakarta: Yayasan Capita Selecta, 1996), 33.
} 


\section{Penutup}

Pemaknaan kembali tentang epistemologi hijrah dalam perspektif historis yang diintegrasikan dengan nilai-nilai normatif melalui kajian hądith secara tematis, kemudian diformulasikan dalam sebuah konsep secara holistik terutama dalam konteks dakwah, maka tampak dengan jelas bahwa hijrah dengan berbagai aspek dan dimensinya dapat berperan sebagai langkah strategis dalam dakwah. D engan demikian, pemaknaan tentang hijrah tidak hanya terkesan hanya sebatas dan sekedar tercatat sebagai doktrinal dan momentum dalam sejarah masa lalu saja, tetapi mampu menciptakan sejarah baru dan kekinian yang dilandasi oleh nilai-nilai normatif, aktual, dinamis dan metodologis seiring dengan kebutuhan dan tuntutan jaman.

\section{Daftar Rujukan:}

Abdullah, M. Amin. "Dialektika Agama antara Profanitas dan Sakralitas", dalam Moh. Shofan, Jalan Ketiga Peikiran Isam Yogyakarta: IRCiSoD, 2006.

Arnold, Sir Thomas W. al-Da'wahilazl-Isam terj. Hasan Ibrahim Hasan, et al. K airo: Maktabat al-Nahdłh al-Misjis t.th.

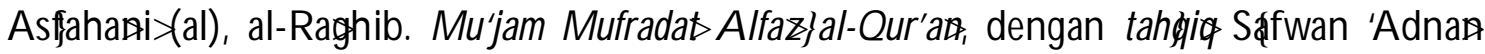
D awudi> Beirut. D as al-Samiyah, 1992.

Azdiłal), Abu» awud Sulayman ibn al-'A sh'ath al-Sijistani>SunanAbu円awud, juz 6. Suriyah:

Das al-Hidith, t.th.

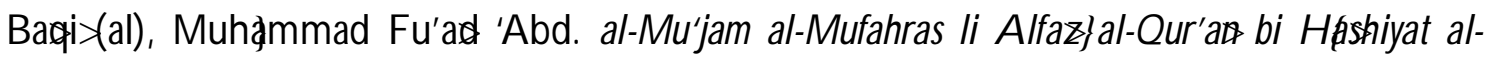
Mushgf al-Shanif t.t.: D as al-Fikr, 1992.

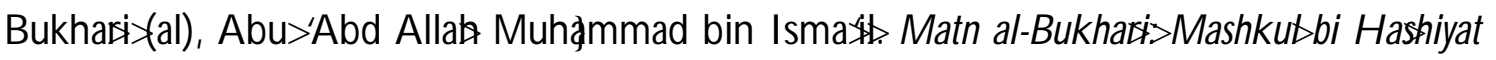
al-Sindi>juz 1-4. Beirut. D as al-Kitab al-Islami>t.th.

Departemen Agama RI. Al-Qứan dan Tejemahnya Madinah: Mujamma‘al-Małik Fahłl li Tæbałat al-Mushigf al-Sharif, $1415 \mathrm{H}$.

Fahman (al), Muhł̧mmad. al-Wáy al-Idaai>Kuwait: t.p., 1971.

Hąnbal, Ahınad ibn. Musnad al-ImamAhhad ibn Hanbal, juz 13. Beirut: al-Maktab al-Islami> 1978.

Hasanuddin. Rhetrika Dakwah dan Pubisitik dalamKepemimpinan Surabaya: Usaha Nasional, 1982.

Hasjmy, A. Dustur Dakwah menunt Al-Qur'an Jakarta: Bulan Bintang, 1984.

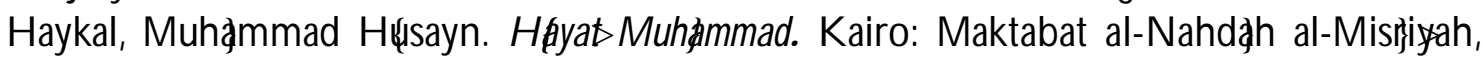
1965.

Hodgson. Marshal G.S. The Venture of Islam: Concience and History in a World Civilization. Chicago: The University of Chicago Press, 1974.

Kartanegara. Mulyadhi. Integasi Ilmi Searah Rekonstruksi Hdistik. Bandung: Arasy Mizan, 2005.

Khuli>(al), al-Baki> Tadkkirab al-Dúat. Mesir: Das al-Kitab al-'Arabi>1952.

Madjid. Nurcholish. Islam Agama Kemanusiaan: Membangun Taradisi dan Visi Baru Indonesia. Jakarta: Yayasan Wakaf Paramadina, 1995.

Mahfuz,\} al-Shaykh ‘Ali> Hidayat al-Murshidin ilasTanuq al-Wa'iz\}wa al-Khitabsah Mesir: al- 
Azhar, 1958.

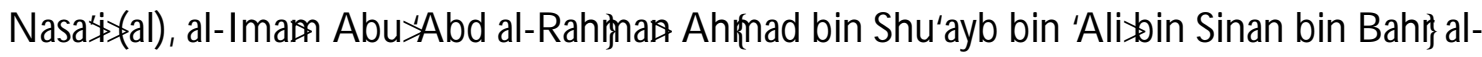
Nasał> Sunan al-Nasa'ì t.t.: t.p., t.th.

Natsir. Mohammad. Fiqhud Dakwah Jgjak Risalah dan Dasar-Dasar Dakwah Jakarta: Yayasan Capita Selecta, 1996.

Nawawi. Talimal-Mutaallim Surabaya: D as al-Maktabah, t.th.

Q asim (al), Muslim al-Hajjajal-Q ushayri

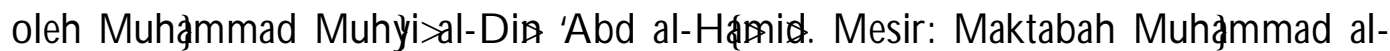
Qubayh, t.th.

Sałd, Amin. Nashat al-Dawah al-Isamiyah Kairo: Isa>al-Babi>al-H łlabi>t.th.

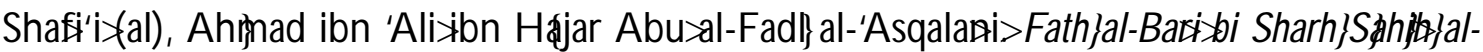
Bukhari>juz 6. Beirut: D as al-Ma'rifah, $1379 \mathrm{H}$.

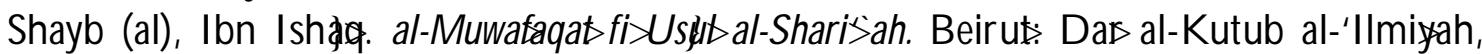
t.th.

Shihab, M. Q uraish. Menbumikan Al-Qư'an Bandung: Mizan, 1992.

Sukarja. A hmad. Piagam Madinah dan UndangUUndang Dasar 1945. Jakarta: UI Press, cet. 1, 1995.

Zahrah. Muhł̧mmad Abu>al-Da'wah ilasal-Isam Beirut: D ass al-Fikr, t.th.

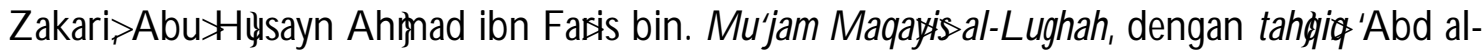
Salam Muhł̨mmad Harun. Beirut: D ał al-Fikr, 1979.

Zuhri, Saifuddin. Seeccah Dakwah Jakarta: Al-Maarif, 1983. 